\title{
PHOTOSYNTHESIS AND PRODUCTIVITY OF POTATO PLANTS IN THE CONDITIONS OF DIFFERENT SPECTRAL IRRADIATION
}

\author{
Yu.Ts. Martirosyan', M.N. Polyakova1, T.A. Dilovarova 1 , A.A. Kosobryukhov1, 2 \\ ${ }^{1}$ All-Russia Research and Development Institute of Agricultural Biotechnology, RAAS, Moscow 127422, Russia \\ e-mail: yumart@yandex.ru \\ ${ }^{2}$ Institute of Fundamental Problems in Biology, RAS, Pushchino 142290, Moscow province, Russia \\ e-mail:kosobr@rambler.ru
}

Received April 9, 2012

S u m m a ry

\begin{abstract}
The authors investigated the effect of light-emitting diode irradiator with maximum in the region of red $\left(\lambda_{\max } 630 \pm 5 \mathrm{~nm}, 660 \pm 5 \mathrm{~nm}\right)$ and blue $\left(\lambda_{\max } 450 \pm 5 \mathrm{~nm}, 470 \pm 5 \mathrm{~nm}\right)$ light on growth processes and activity of photosynthetic apparatus in potato plants of the Nevskii early variety. It was made a conclusion, that application of light-emitting diode irradiators in controllable conditions of phytotron may be useful technique during potato growing subject to changes of spectrum composition in plant ontogenesis.
\end{abstract}

Keywords: potato, photosynthesis, growth, light diodes.

In natural conditions of plant vegetation, daylight provides illumination of quite variable intensity and spectral composition. Controlled environment with adjustable lightning allows setting the parameters required by a plan of experiment and provide an optimum light program for improved efficiency of plant growth.

Photoculture commonly uses different types of electric lamps (1). For plants it is essential that light must include all visible spectral regions with prevailing red, green, blue, and violet rays, as well as a small proportion of ultraviolet and infrared light. Currently, the most widely used lamps are high-pressure gas-discharge lamps - metal-halide lamps (MHL, maximum emission at 450 $\mathrm{nm}$ ) and high-pressure sodium lamps (HPS, maximum emission at $590 \mathrm{~nm}$ ) of 400 and $600 \mathrm{~W}(1,2)$. However, using gas-discharge lamps in plant growing is associated with significant energy expenditure and insufficient spectral properties of light emitters. A possible solution of this problem is low-energy light-emitting diodes (LEDs).

LEDs can be used as supplement light sources, though they are expected to completely replace traditional lamps in photoculture $(3,4)$, especially in enclosed cultivation systems. Today the authors are developing new approaches to production of improved planting material of potato in aeroponics with LED illumination $(5,6)$.

Main effects of broadband red and blue light on photosynthetic apparatus and metabolic processes of plants were discovered in 1960-1980ies $(7,8)$, but many issues are still unclear - particularly, the effect of narrowband red and blue light on basic parameters of photosynthesis and productivity. The available scientific literature describes the effects of LED light on primary stages of photosynthesis (4) and growth processes (9).

The purpose of this work was studying growth and development of potato plants improved against phytopathogens during vegetation under LED illumination, as well as the study of the activity of photosynthetic apparatus and individual elements of carboxylation cycle.

Technique. Experiments were performed on plants grown in factor-static conditions at $18-20{ }^{\circ} \mathrm{C}$ and 16 hour photoperiod. Improved minitubers of potato cv Nevsky were planted in a 5-liter vegetation containers filled with soil substrate and placed under different light sources: HPS-600 W ("Phillips", the Netherlands) and LEDs (developed in the All-Russia Research and Development Institute of Agricultural Biotechnology in collaboration with the company "Focus", Russia; 1 LED = $1 \mathrm{~W}$ ), with illumination maxima of $660+450$ (red $660 \mathrm{~nm}+$ blue $450 \mathrm{~nm}$, ratio 40:20), and $630+470$ (red $630 \mathrm{~nm}+$ blue $470 \mathrm{~nm}$, ratio 48:24), light intensity at the upper leaf height - respectively 240-260, 260-280, and 130-140 umol photons $\mathrm{Lm}^{-2} \mathrm{Łs}^{-1}$.

Gas exchange was measured with a portable infrared gas analyzer LCPro+ (“ADC BioScientific Ltd.”, UK) connected to a clamp-on leaf chamber (area $6,25 \mathrm{~cm}^{2}$ ). To determine the light dependence of $\mathrm{CO}_{2}$ gas exchange in leaves, illumination was consistently increased from 0 to 1200 umol photons $\mathrm{Lm}^{-2} \mathrm{Ls}^{-1}$. The light curve was approximated by the model of J.L. Priol and P. Chartier (10). To construct carbon-dioxide curves using microprocessor of the gas analyzer it was set $\mathrm{CO}_{2}$ content in the air ranging from 0 to 2400 umol $\mathrm{CO}_{2} \mathrm{Lmol}^{-1}$. The curve of $\mathrm{CO}_{2}$ gas exchange was analyzed using the model of G.D. Farquhar et al. (11) at a modified version $(12,13)$. The model allows determining the maximum rate of carboxylation of ribulose bisphosphate carboxylase / oxygenase (Rubisco), the rate of electron transfer at light saturation, as well as the rate of utilization of triosophosphates that reflects availability of inorganic phosphate for Calvin cycle. These parameters were calculated according to the model with equations corresponding to different stages of limitation of the dependence between carbon dioxide and $\mathrm{CO}_{2}$ gas exchange.

The content of pigments was determined in leaves homogenized in a porcelain mortar with the addition of $\mathrm{CaCO}_{3}$ and extracted with $80 \%$ acetone. Chlorophyll absorption was measured on a spectrophotometer Spekol-11 ("Carl Zeiss", Germany), calculations were performed according to Nibom (14).

In early period of vegetation, accumulation of biomass was evaluated in variants of the experiment. The number and weight of tubers were recorded at the end of the experiment. The following data show arithmetic mean results of a typical experiment and their standard deviations.

Results. Plants grown under HPS lamps developed the highest rate of growth (by accumulation of biomass in aerial parts) in 3 weeks after the start of vegetation $(59,5 \pm 4,2 \mathrm{~g} /$ plant). Under LED $630+470$ and LED $660+450$, the accumulated plant biomass amounted to, resp., 66,0 $\pm 2,4$ and 26,6 $\pm 1,5 \mathrm{~g} /$ plant. Along with it, plants under HPS lamps and LED $630+470$ showed a higher rate of

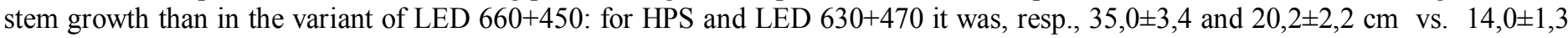
cm for LED $660+450$.

It should be noted that higher rate of growth under LED 630+470 compared with LED 660+450 wasn't related to the rate of $\mathrm{CO}_{2}$ assimilation per unit leaf area. Carbon dioxide uptake in plants under LED $630+470$ was $6,92 \pm 0,20 \mathrm{umol} \mathrm{CO}_{2} \mathrm{Lm}^{-2} \mathrm{Ls}{ }^{-1}$. For HPS

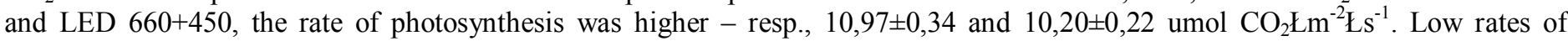


photosynthesis under LED 630+470 were associated with less efficient activity of photosynthetic apparatus. For example, in the variant of LED 630+470, quantum efficiency of photosynthesis and the rate of $\mathrm{CO}_{2}$ uptake in the light saturation were lower than those in other variants (Table 1). $\mathrm{CO}_{2}$-curve of photosynthesis for the experimental conditions of lightning showed that the rate of photosynthesis at saturating content of $\mathrm{CO}_{2}$ for LED 630+470 was also lower than in both other cases (Table 2).

1. Parameters of light curves of $\mathrm{CO}_{2}$-gas exchange in leaves of improved potato plants $\mathrm{cv}$ Nevsky grown in photoculture with light of different spectral composition $(X \pm x)$

\begin{tabular}{|c|c|c|c|}
\hline \multirow{2}{*}{ Parameter } & \multirow{2}{*}{$\begin{array}{l}\text { Lamp } \\
\text { HPS-600 }\end{array}$} & \multicolumn{2}{|c|}{ Light emitting diode, $\mathrm{nm}$} \\
\hline & & $660+450$ & $630+470$ \\
\hline Light saturation of photosynthesis, umol $\mathrm{CO}_{2} \mathrm{Lm}^{-2} \mathrm{Ls}^{-1}$ & $32,4 \pm 1,4$ & $59,7 \pm 2,4$ & $23,9 \pm 2,1$ \\
\hline Rate of $\mathrm{CO}_{2}$ emission in the dark, umol $\mathrm{CO}_{2} \mathrm{Lm}^{-2} \mathrm{Ls}^{-1}$ & $-3,1 \pm 0,3$ & $-3,8 \pm 0,7$ & $-3,2 \pm 0,4$ \\
\hline Quantum efficiency of photosynthesis, umol $\mathrm{CO}_{2}$ Łumoll $^{-1}$ (photon) & $0,080 \pm 0,008$ & $0,090 \pm 0,007$ & $0,039 \pm 0,007$ \\
\hline Light compensational point, umol (photon) $\mathrm{Lm}^{-2} \mathrm{Ls}^{-1}$ & $38,9 \pm 3,2$ & $41,8 \pm 2,1$ & $80,6 \pm 4,1$ \\
\hline Light intensity at saturation, umol (photon) $\mathrm{Lm}^{-2} \mathrm{Ls}^{-1}$ & $442,0 \pm 5,4$ & $706,0 \pm 6,2$ & $681,0 \pm 6,2$ \\
\hline
\end{tabular}

2. Parameters of approximated curves of $\mathrm{CO}_{2}$ - gas exchange in leaves of improved potato plants cv Nevsky grown in photoculture with light intensity corresponding to growing conditions $(X \pm x)$

\begin{tabular}{|c|c|c|c|}
\hline \multirow{2}{*}{ Parameter } & \multirow{2}{*}{$\begin{array}{l}\text { Lamp } \\
\text { HPS-600 }\end{array}$} & \multicolumn{2}{|c|}{ Light emitting diode, $\mathrm{nm}$} \\
\hline & & $660+450$ & $660+450$ \\
\hline Maximum rate of $\mathrm{CO}_{2}$ absorption, umol $\mathrm{CO}_{2} \mathrm{Lm}^{-2} \mathrm{Ls}^{-1}$ & $25,2 \pm 2,2$ & $38,0 \pm 1,2$ & $24,6 \pm 3,5$ \\
\hline Maximum rate of carboxylation, umol $\mathrm{CO}_{2} \mathrm{Lm}^{-2} \mathrm{Ls}^{-1}$ & $39,6 \pm 1,8$ & $25,4 \pm 0,7$ & $21,4 \pm 2,4$ \\
\hline Efficiency of carboxylation, umol $\mathrm{CO}_{2} \mathrm{Lm}^{-2} \mathrm{Ls}^{-1} \mathrm{LPa}^{-1}$ & $0,80 \pm 0,30$ & $0,42 \pm 0,10$ & $0,47 \pm 0,10$ \\
\hline Electron-transfer rate, umol $\mathrm{Lm}^{-2} \mathrm{Ls}^{-1}$ & $70,6 \pm 3,8$ & $80,7 \pm 0,3$ & $66,7 \pm 3,4$ \\
\hline Rate of utilization of triosophosphates, umol $\mathrm{Łm}^{-2} \mathrm{Ls}^{-1}$ & $5,0 \pm 0,4$ & $5,9 \pm 0,2$ & $4,9 \pm 0,3$ \\
\hline Rate of $\mathrm{CO}_{2}$ emission in the dark, umol $\mathrm{CO}_{2} \mathrm{Lm}^{-2} \mathrm{Ls}^{-1}$ & $-2,8 \pm 0,3$ & $-1,5 \pm 0,5$ & $-2,2 \pm 0,7$ \\
\hline $\mathrm{CO}_{2}$ compensational point, umol $\mathrm{CO}_{2}$ & 41,4 & 25,0 & 32,7 \\
\hline
\end{tabular}

The observed effects may be related to a higher chlorophyll content per unit of raw leaf biomass in plants under LED $660+450(1,550 \mathrm{mg} / \mathrm{g})$ compared to that for LED $630+470(1,260 \mathrm{mg} / \mathrm{g})$, as well as a higher rate of light photosynthetic processes (e.g. electron transfer) under LED $660+450$ and, therefore, faster regeneration of ribulose bisphosphate. However, high activity of photosynthetic apparatus in plants grown under LED 660+450 wasn't realized in plants and didn't lead to increased accumulation of aboveground biomass in early period of growth compared to the variant with LED $630+470$.

The observed imbalance between the intense functioning of photosynthetic apparatus in plants and accumulation of biomass in early period of growth under LED $630+470$ relative to the variant of LED $660+450$ was associated with greater (2,1 times) assimilating structures developed by plants in the first case. These results are consistent with reports about formation of extra assimilation surface in plants exposed to a low light intensity (15).

Light intensity levels used in this experiment resulted from, on the one hand, technical characteristics of modern LEDs available in the market, on the other - by the need in relatively low light intensity during the adaptive period of growing in aeroponic system for plants earlier cultured in vitro.

The optimum light intensity for potato photoculture is $200-250 \mathrm{~W} / \mathrm{m}^{2}$ (16), which corresponds to $800-1000$ umol photons $\mathrm{Lm}^{-2} \mathrm{Ls}^{-1}$ in the range of photosynthetically active radiation. The limiting factors for functioning of the photosynthetic apparatus under saturating light intensity (i.e., characteristics of its potential) were revealed by analysis of the curves of $\mathrm{CO}_{2}$ gas exchange in plants under $1200 \mathrm{umol}$ photons $\measuredangle \mathrm{m}^{-2} \mathrm{Ls}^{-1}$. It was found that the low rate of photosynthesis in plants under LED 630+470 resulted from a low activity of Rubisco and limitations of the light photosynthetic processes - electron transfer and regeneration of ribulose bisphosphate (Table 3). Thus, the rate of $\mathrm{CO}_{2}$ uptake by leaf area unit at light saturation under LED 630+470 was 23,9 1 , 1, and for LED 660+450 $59,7 \pm 2,4 \mathrm{umol} \mathrm{Lm}^{-2} \mathrm{Ls}^{-1}$. These data are explainable: absorption maxima of the pigments are closer to 660 and $450 \mathrm{~nm}$ of the second LED variant.

3. Parameters of approximated curves of $\mathrm{CO}_{2}$ - gas exchange in leaves of improved potato plants cv Nevsky grown in photoculture with saturating light intensity $(X \pm x)$

\begin{tabular}{|c|c|c|c|}
\hline \multirow{2}{*}{ Parameter } & \multirow{2}{*}{$\begin{array}{l}\text { Lamp } \\
\text { HPS-600 }\end{array}$} & \multicolumn{2}{|c|}{ Light emitting diode, $\mathrm{nm}$} \\
\hline & & $660+450$ & $660+450$ \\
\hline Maximum rate of $\mathrm{CO}_{2}$ absorption, umol $\mathrm{CO}_{2} \cdot \mathrm{m}^{-2} \cdot \mathrm{s}^{-1}$ & $58,6 \pm 2,9$ & $67,0 \pm 5,2$ & $61,3 \pm 3,4$ \\
\hline Maximum rate of carboxylation, umol $\mathrm{CO}_{2} \cdot \mathrm{m}^{-2} \cdot \mathrm{s}^{-1}$ & $63,6 \pm 1,5$ & $95,5 \pm 2,4$ & $66,3 \pm 1,6$ \\
\hline Efficiency of carboxylation, umol $\mathrm{CO}_{2} \cdot \mathrm{m}^{-2} \cdot \mathrm{s}^{-1} \cdot \mathrm{Pa}^{-1}$ & $1,4 \pm 0,2$ & $2,2 \pm 0,4$ & $1,4 \pm 0,2$ \\
\hline Electron-transfer rate, umol $\cdot \mathrm{m}^{-2} \cdot \mathrm{s}^{-1}$ & $200,5 \pm 4,8$ & $254,7 \pm 5,0$ & $214 \pm 5,5$ \\
\hline Rate of utilization of triosophosphates, umol $\cdot \mathrm{m}^{-2} \cdot \mathrm{s}^{-1}$ & $23,6 \pm 1,8$ & $18,6 \pm 1,4$ & $19,4 \pm 1,9$ \\
\hline Rate of $\mathrm{CO}_{2}$ emission in the dark, umol $\mathrm{CO}_{2} \cdot \mathrm{m}^{-2} \cdot \mathrm{s}^{-1}$ & $-5,5 \pm 1,5$ & $-9,2 \pm 3,6$ & $-6,0 \pm 1,6$ \\
\hline $\mathrm{CO}_{2}$ compensational point, umol $\mathrm{CO}_{2}$ & 48,2 & 65,8 & 56,4 \\
\hline
\end{tabular}

At the end of vegetation, plants exposed to LED $630+470 \mathrm{~nm}$ produced 18,6 g tubers per plant, while under LED $660+450$ $\mathrm{nm}$ the yield of tubers was $176,1 \mathrm{~g}$, and HPS-600 - 183,6 g/plant. The observed effect of LED illumination on plants' productivity may be caused by a hormonal balance in ontogeny. According to the literature (17), light radiation with prevailing red spectral range increases accumulation of gibberellins in aerial parts of plants leading to increased leaf area. This fact is important in early period of growth, which was demonstrated by the variant of LED $630+470$ with red/blue ratio $=2,09$ and the area of leaf surface 2,1 times exceeding that of plants grown under LED $660+450$. The effect of blue range of light radiation (variant LED $660+450 \mathrm{with}$ red/blue ratio $=1,43)$ on accumulation of cytokinins in underground parts of plants is important at the end of vegetation as it promotes formation of tubers (18).

So, these findings show the effects of different light sources (LEDs, HPS lams) on growth processes of potato plants and activity of their photosynthetic apparatus in ontogeny. High rate of carbon dioxide uptake in plants grown under LED $660+450 \mathrm{~nm}$ in experimental conditions, as well as at increased concentrations of $\mathrm{CO}_{2}$, or at light saturation is associated with more efficient 
functioning of individual elements of the carbonation cycle, which reflects the greater potential activity of photosynthetic apparatus in these plants compared with the variant of LED $630+470 \mathrm{~nm}$. The final yield of tubers from plants grown under LED $660+450$ is comparable with that for HPS-600 lamps, which indicates the possibility of using LED luminaries in controlled aeroponic culture of potato. However, the light spectrum not including other spectral regions playing important regulatory functions limits realization of photosynthetic potential. For optimum growth, development, and maximum yield of plants it is necessary that LED light must include all spectral regions with predominance of red, green, blue, and violet rays, as well as a small proportion of ultraviolet and infrared light. The role of each individual region of light spectrum and their various combinations will be studied in future experiments .

\section{REFERENCES}

1. Volkov V.N., Sventitskii I.I., Storozhev P.I., Tsareva L.A. Iskusstvennoe obluchenie rastenii [Artificial Illumination]. Pushchino, 1982.

2. Tikhomirov A.A., Lisovskii G.M., Sid'ko F.Ya. Spektral'nyi sostav sveta i produktivnost' rastenii [Light Spectrum Components and Productivity of Plants]. Novosibirsk. 1991.

3. Yorio N.C., Goins G.D., Kagie H.K., Wheeler R.M., Sager J.C. Improving spinach, radish, and lettuce growth under red light-emitting diodes (LEDs) with blue light supplementation. Hort. Sci., 2001, 36: 380-383.

4. Avercheva O.V., Berkovich Yu.A., Erokhin A.N., Zhigalova T.V., Pogosyan S.I., Smolyanina S.O. Fiziologiya rastenii, $2009,56: 17-26$.

5. Martirosyan Yu.Ts., Kosobryukhov A.A., Kreslavskii V.D., Melik-Sarkisov O.S. Kartofelevodstvo (Potato Growing: Compilation of Sci. Works). Minsk, 2007, v. 13: $65-73$.

6. Martirosyan Yu.Ts., Kosobryukhov A.A., Kreslavskii V.D., Dilovarova T.A., Melik-Sarkisov O.S., Letunova S.V., Kharchenko P.N. Sel'skokhozyaistvennaya Biologiya [Agricultural Biology], 2008, 3: 102-105.

7. Kursanov A.L., Voskresenskaya N.P. Fotoregulyatsiya metabolizma i morfogeneza rastenii [Photoregulation of Plant Metabolism and Morphogenesis: Compilation of Sci. Works]. Moskva, 1975: 16-36.

8. Bukhov N.G., Drozdova I.S., Bondar V.V., Mokronosov A.T. Blue, red and blue plas red light control of chlorophyll content and CO 2 gas exchange in barley leaves: quantitative description of the effects of light quality and fluence rate. Physiol. Plant., 1992, 85: 632-639.

9. Moroz D.S., Astasenko N.I., Tsvirko V.I. Fiziologo-biokhimicheskie osnovy produktsionnogo protsessa u kul'tiviruemykh rastenii [Physiological and Biochemical Bases of Production Process in Cultivated Plants: Compilation of Sci. Works]. Saratov, 2010: 58-60.

10. Priol J.L., Chartier P. Partitioning of transfer and carboxilation components of intracellular resistance to photosynthetic $\mathrm{CO}_{2}$ fixation: A critical analisis of the methods used. Annals of Botany, 1977, 41: 789-800.

11. Farquhar G.D., Von Caemmerer S. Berry J.A. A biochemical model of photosynthetic $\mathrm{CO}_{2}$ assimilation in leaves of C3 plants. Planta, 1980 , 149(1): 78-90.

12. Harley P.C., Sharkey T.D. An improved model of C3 photosynthesis at high $\mathrm{CO}_{2}$ : Reserved $\mathrm{O}_{2}$ sensitivity explained by lack of glycerate re-entry into the chloroplast. Photosynthesis Research, 1991, 27: 169-178.

13. Harley P.C., Thomas R.B., Reynolds J.F., Strain B.R. Modelling photosynthesis of cotton grown in elevated CO 2 . Plant Cell and Environment, 1992, 1: $271-282$.

14. Limar' R.S., Sakharova O.V. Metody kompleksnogo izucheniya fotosinteza [Methods for Comprehensive Study of Photosynthesis]. Leningrad,

v. 2, 1973, 58-62.

15. Tsel'niker Yu.L., Osipova O.P., Nikolaeva M.K. Fiziologiya fotosinteza [Physiology of Photosynthesis: Compilation of Sci. Works]. Moskva, 1982: 187-202.

16. Lebedeva E.V., Simonov V.M., Vil'yams V.M. Printsipy upravleniya produktsionnymi protsessami v agroekosistemakh [Fundamental Regulations of Productive Processes in Agroecosystems: Compilation of Sci. Works]. Moskva, 1976: 144-152.

17. Voskresenskaya N.P., Drozdova I.S., Aksenova N.P. et al. Regulyatsiya rosta i razvitiya kartofelya [Regulation of Growth and Development in Potato: Compilation of Sci. Works]. Moskva, 1990: 20-29.

18. Chailakhyan M.Kh. Regulyatsiya rosta i razvitiya kartofelya [Regulation of Growth and Development in Potato: Compilation of Sci. Works]. Moskva, $1990: 48-62$. 